\title{
sciendo
}

Current Issues in Pharmacy and Medical Sciences

Formerly ANNALES UNIVERSITATIS MARIAE CURIE-SKLODOWSKA, SECTIO DDD, PHARMACIA

\section{Clinical and laboratory findings of patients with the possible diagnosis of influenza hospitalized in affiliated hospitals of Babol University of Medical Sciences, 2015-2016}

\author{
Mostafa Javanian, Arefeh Babazadeh, Soheil Ebrahimpour, \\ MeHran SHOKRI, MaSOMEH BAYANI ${ }^{*}$
}

Infectious Diseases and Tropical Medicine Research Center, Health Research Institute, Babol University of Medical Sciences, Babol, I.R. Iran

\begin{tabular}{|c|c|}
\hline ARTICLE INFO & ABSTRACT \\
\hline $\begin{array}{l}\text { Received } 17 \text { January } 2018 \\
\text { Accepted } 15 \text { March } 2018\end{array}$ & $\begin{array}{l}\text { The clinical and para clinical manifestations of influenza in various patients have range } \\
\text { from an autoimmune disease to a life-threatening respiratory infection. In addition, the }\end{array}$ \\
\hline $\begin{array}{l}\text { Keywords: } \\
\text { H1N1 influenza, } \\
\text { clinical and laboratory } \\
\text { findings, } \\
\text { Iran. }\end{array}$ & $\begin{array}{l}\text { severity of the disease is influenced by factors such as demographic factors, underlying } \\
\text { diseases, and immune response. Therefore, in this study, we evaluated the clinical, } \\
\text { laboratory and epidemiological characteristics of patients with this type of influenza } \\
\text { in Babol (north of Iran). This study was conducted as a descriptive cross-sectional study } \\
\text { from October } 2015 \text { to March } 2016 \text {. Subsequently, in this study, records of } 123 \text { patients } \\
\text { with clinical signs of the influenza-like disease who have undergone the clinical sign in } \\
\text { hospitals affiliated to Babol University of Medical Sciences were reviewed. Of } 123 \text { patients } \\
\text { admitted to a possible diagnosis of influenza, } 58 \text { patients ( } 47.2 \% \text { ) were PCR positive for } \\
\text { H1N1, while seventy nine (64.2\%) participants were women and } 21 \text { (17.1\%) had diabetes } \\
\text { or underlying lung disease. Most of the involved age groups were of individuals above } \\
\text { the age of } 50 \text {. These were followed by the } 21-35 \text { years-old. Fever (78\%), cough (65.9\%), } \\
\text { shivering (58.5\%) and myalgia (56.1\%) were the most common clinical symptoms. } \\
\text { Increased levels of transaminases ( } 43.1 \%) \text {, leukocytosis ( } 35.8 \%) \text { and thrombocytopenia } \\
\text { ( } 34.2 \%) \text { were as well reported in patients as the most frequently reported para clinical } \\
\text { findings. In the present study, the most usual clinical symptoms were fever, cough, chill, } \\
\text { and myalgia, while gastrointestinal symptoms were also noticeably observed in patients. } \\
\text { In an experimental study, a significant number of patients showed leukocytosis and } \\
\text { thrombocytopenia and increased transaminases. }\end{array}$ \\
\hline
\end{tabular}

\section{INTRODUCTION}

In 2009, a new swine flu H1N1 influenza virus wherein the genomic segments were derived from four different sources (quadruple rearrangement) was described in two patients. It then spread throughout the world in a short time. This pandemic agent had the greatest impact on children and adolescents $[1,2]$. Like other influenza strains, it is transmitted individually to the individual through coughing, sneezing and occasionally by contact with virus-infected objects. Symptoms, with a 2-7 day incubation period, include fever, chills, coryza, sore throat and gastrointestinal symptoms that do not differ from other strains [3]. Interestingly, more young and middle-aged adults are involved, while different

\footnotetext{
* Corresponding author

e-mail: dr.bayani1@yahoo.com
}

pulmonary and sometimes extra-pulmonary complications have been reported, including viral, bacterial or both pneumonia, encephalopathy and encephalitis, Guillain-Barré syndrome (GBS), toxic shock syndrome (TSS), myositis, myoglobinuria, myocarditis, and pericarditis [4-7]. In some groups, mortality and morbidity are more often reported. These include pregnant women or women in preterm delivery, children under the age of 5, people with underlying diseases or immune deficiency, chronic aspirin users and people with obesity, mortality and morbidity [8,9]. It should be noted that all strains ( $\mathrm{pH} 1 \mathrm{~N} 1)$ are completely resistant to $\mathrm{M} 2$ inhibitors [10].

Although the most efficacious treatment is when it is started within 48 hours of onset of symptoms, recent experience regarding this infection has shown that treating patients 
with progressive disease, especially if they are still positive for the PCR, is beneficial even in the late phase [11]. Since the symptoms of seasonal H1N1 influenza in the period 2014-2015 in Iran were different from earlier years, and because early diagnosis can play a significant role in the prognosis of disease, we decided to show and evaluate clinical and laboratory findings of patients hospitalized in Babol University of Medical Sciences hospitals during this outbreak.

\section{MATERIALS AND METHODS}

In this descriptive cross-sectional study, nasopharyngeal swabs for influenza was taken from all patients with flu-like symptoms who were admitted to Babol University of Medical Sciences hospitals from October 2015 to March 2016. Samples, in a cold-pack transport medium, were then transferred to the Central Laboratory for RT-PCR. Demographic data and clinical and laboratory findings were also gathered via questionnaires. The research was approved by the Ethics Committee of Babol University of Medical Sciences. All of the data were analyzed using SPSS16 software and statistical methods. P-value $\leq 0.05$ was considered statistically significant.

\section{RESULTS}

In this study, 123 patients were admitted with a possible diagnosis of influenza, of which $58(47.2 \%)$ were positive for nasopharyngeal secretions PCR in H1N1. Most of the patients were women (64.2\%). Overall, the mean age of the patients was $48.6 \pm 20.5$. The majority of all patients (43.1\%) were primarily in the above 50 age group and then secondarily in the age group of 21-35 years (32.5\%) (Table 1). In the study of underlying diseases, 14 patients $(11.4 \%)$ were diabetics and 7 patients $(5.7 \%)$ had underlying pulmonary diseases. In addition, five patients (4.1\%) were smokers and $5(4.1 \%)$ persons were addicts. The most common clinical symptoms of the patients with this diagnosis were: fever in 96 patients $(78 \%)$, cough in 81 patients $(65.9 \%)$, chill in $72(58.5 \%)$ and myalgia in $69(56.1 \%)$, respectively. It should be noted that a significant number of patients, $31(25.2 \%)$, were referred with gastrointestinal symptoms. In comparison, nasal congestion $(8.9 \%)$ and arthralgia $(0.4 \%)$ were the rarest manifestations of patients (Table 2$)$. In examining the symptoms of the patients at the time of entry, $71(57.7 \%)$ had fever and $8(6.5 \%)$ had hypothermia. Furthermore, thirty six patients $(29.3 \%)$ had hypotension at the time of referral, 48 (39\%) patients were tachypnic and $69(56.1 \%)$ had tachycardia (Table 3). Moreover, in the present study, via the laboratory results, 13 patients $(10.6 \%)$ were found to have leukopenia and $44(35.8 \%)$ had leukocytosis. Thrombocytopenia was also seen in 42 patients (34.2\%). Beyond the aforementioned, electrolyte evaluation revealed hyponatremia in 12 patients $(9.8 \%)$, and the level of transaminases was high in 53 patients (43.1\%). Evaluating the renal function also showed that 24 patients $(19.5 \%)$ had increased creatinine, while 45 patients $(36.6 \%)$ had ESR above 30 and 39 (31.7\%) had CRP over 50 (Table 4). The mean hospitalization time was $7.11 \pm 5.9$ days.
Table 1. Demographical data of suspected H1N1 patients

\begin{tabular}{|l|c|c|}
\hline \multirow{3}{*}{ Age } & Variable & Frequency (\%) \\
\cline { 2 - 3 } & $20 \geq$ & $4(3.25)$ \\
\cline { 2 - 3 } & $21-35$ & $40(32.52)$ \\
\cline { 2 - 3 } & $36-50$ & $26(21.13)$ \\
\hline \multirow{3}{*}{ Sex } & $50 \leq$ & $53(43.08)$ \\
\hline Smoking & Male & $44(35.77)$ \\
\hline Addiction & Female & $79(64.22)$ \\
\hline Diabetes & & $5(4.06)$ \\
\hline Respiratory disease & $5(4.06)$ \\
\hline Duration of admission & $14(11.38)$ \\
\hline
\end{tabular}

Table 2. Clinical features presented by suspected H1N1 patients

\begin{tabular}{|l|c|}
\hline \multicolumn{1}{|c|}{ Sign } & (\%)Frequency \\
\hline Fever & $96(78)$ \\
\hline Chilling & $72(58.5)$ \\
\hline myalgia & $69(56.1)$ \\
\hline Headache & $40(32.5)$ \\
\hline Cough & $81(65.9)$ \\
\hline Sore throat & $37(30.1)$ \\
\hline Sputum & $51(41.5)$ \\
\hline Chest pain & $18(14.6)$ \\
\hline Dyspnea & $62(50.4)$ \\
\hline Rhinorrhea & $25(20.3)$ \\
\hline Nasal congestion & $11(8.9)$ \\
\hline Diarrhea & $7(5.7)$ \\
\hline Constipation & $1(0.8)$ \\
\hline Anorexia & $23(18.7)$ \\
\hline Arthralgia & $3(0.42)$ \\
\hline
\end{tabular}

Table 3. Vital signs presented by suspected H1N1 patients

\begin{tabular}{|l|c|c|}
\hline \multirow{2}{*}{ Heart rate } & Variable & $(\%)$ Frequency \\
\hline \multirow{3}{*}{ Respiratory rate } & $90 \geq$ & $51(41.5)$ \\
\cline { 2 - 3 } & $90<$ & $69(56.1)$ \\
\hline \multirow{3}{*}{ Blood Pressure } & $20 \geq$ & $69(56.1)$ \\
\cline { 2 - 3 } & $20<$ & $48(39)$ \\
\cline { 2 - 3 } & $90 \geq$ & $36(29.3)$ \\
\hline \multirow{3}{*}{ Temperature } & $90-140$ & $74(60.2)$ \\
\cline { 2 - 3 } & $140<$ & $11(8.9)$ \\
\cline { 2 - 3 } & $36.5 \geq$ & $8(6.5)$ \\
\cline { 2 - 3 } & $36.6-37.7$ & $40(32.5)$ \\
\hline
\end{tabular}

\section{DISCUSSION}

According to studies conducted in Iran, the number of proven $\mathrm{H} 1 \mathrm{~N} 1$ cases in 2009 was reported to be about 3700 , of which 1,000 (27\%) were hospitalized. The mortality rate was $140(3.8 \%)$ [12]. In the present study, of 123 patients diagnosed with the possible diagnosis of influenza, 
Table 4. Para- clinical features presented by suspected H1N1 patients

\begin{tabular}{|c|c|c|}
\hline & Variable & Frequency (\%) \\
\hline \multirow{3}{*}{ WBC } & $4000>$ & $13(10.57)$ \\
\hline & $4000-10000$ & 65 (52.9) \\
\hline & $10000<$ & $44(35.8)$ \\
\hline \multirow{2}{*}{$\mathrm{Hb}$} & $10 \geq$ & $42(34.2)$ \\
\hline & $10<$ & $80(65)$ \\
\hline \multirow{2}{*}{ Platelet } & $150000 \geq$ & $42(34.2)$ \\
\hline & $150000<$ & $79(64.2)$ \\
\hline \multirow{2}{*}{ ESR } & $30 \geq$ & $59(48)$ \\
\hline & $30<$ & $45(36.6)$ \\
\hline \multirow{3}{*}{ CRP } & $10 \geq$ & $11(9)$ \\
\hline & $11-50$ & $45(36.6)$ \\
\hline & $50<$ & 39 (31.7) \\
\hline \multirow{2}{*}{$\mathrm{Cr}$} & $1.5>$ & $95(77.2)$ \\
\hline & $1.5 \leq$ & $24(19.5)$ \\
\hline \multirow{2}{*}{ AST } & $40<$ & $32(26)$ \\
\hline & $40 \geq$ & $53(43.1)$ \\
\hline \multirow{2}{*}{ ALT } & $40<$ & $34(27.6)$ \\
\hline & $40 \geq$ & $50(40.7)$ \\
\hline \multirow{2}{*}{ ALK } & $350>$ & $61(49.6)$ \\
\hline & $350 \leq$ & $10(8.1)$ \\
\hline \multirow{2}{*}{ BS } & $120>$ & $61(49.6)$ \\
\hline & $120 \leq$ & $46(37.4)$ \\
\hline \multirow{3}{*}{$\mathrm{Na}$} & $130>$ & $12(9.8)$ \\
\hline & $130-150$ & $102(83)$ \\
\hline & $150<$ & $2(1.6)$ \\
\hline \multirow{3}{*}{$\mathrm{k}$} & $3>$ & $1(0.8)$ \\
\hline & 3-5.5 & $111(90.2)$ \\
\hline & $5.5<$ & $1(0.8)$ \\
\hline \multirow{2}{*}{ PT } & $13>$ & 38 (30.9) \\
\hline & $13 \leq$ & $63(51.2)$ \\
\hline
\end{tabular}

a positive PCR for H1N1was detected in 58 (47.2\%), which is higher than other studies in our country [13]. This can be because of better sampling and more precise clinical suspicion in the diagnosis of patients, even though it is probable that true H1N1 cases are higher and our test had also false negative results because of treatment having begun before testing. Most of the affected patients, as in other studies, were female $(64.2 \%)$. Since pregnant women form the majority of the population at high risk of influenza, and this fact leads to hospitalization, a higher incidence of this disease is, hence, normally expected in women [14-16]. In the age study, patients with severe influenza leading to being hospitalized were mostly in the age group of over $50(43.1 \%)$ and then in the age group of $21-35(32.5 \%)$. These findings can be justified by the relative decrease of the immune system function in elderly age, as well as the absence of protective antibodies due to the previous nonexposure to the same strains in younger individuals. Also, in the present study, the most common clinical symptoms of hospitalized patients were fever (78\%), cough (65.9\%), shivering (58.5\%) and myalgia (56.1\%), which, regardless of the type of strain, is consistent with the symptoms of influenza reported in different sources [17]. An interesting point was the prevalence $(25.2 \%)$ of gastrointestinal symptoms in patients. This was also found in other similar studies of H1N1 influenza $[18,19]$. This last is, therefore, a good guide for the timely diagnosis of influenza patients who are referred with gastrointestinal manifestations. Similar to other studies, tachypnea (39\%) and tachycardia (56.1\%) have been commonly observed in the patients' vital signs, while hypokalemia (6.5\%) and hyponatremia $(29.3 \%)$ have been reported in some cases. As expected in other viral infections, leukopenia (10.6\%) and thrombocytopenia (34.2\%) were also observed in some patients. What is more, leukocytosis was seen in $35.8 \%$ of all patients. This figure is the same as that revealed in some other studies. Such a statistic could be due to the coincidence of bacterial infection in these patients or the administration of corticosteroids drugs before their referral, to reduce symptoms [20,21]. Also, in $19.5 \%$ of all patients, the amount of creatinine was seen to increase, while $43.1 \%$ showed asymptomatic hepatitis as an increase in transaminases, which demonstrated that influenza can affect the other organs. Of note, increased inflammatory factors, including ESR and CRP, are not unexpected during the course of influenza, especially in severe, complicated cases accompanied with bacterial infections [22].

The number of patients in this study were not many, including few patients that fall within the 20 years old bracket. Therefore, more research is needed, with more sampling. Furthermore, laboratory tests used to detect influenza have not been standardized and commercial kits have been used. In addition, sampling, transfer and storage problems may lead to a false positive PCR.

\section{CONCLUSION}

In the present study, most patients with influenza leading to hospitalization were women, and the most involved age groups were senior adults and youths. In a significant number of patients, diabetes and chronic lung disease were reported as the underlying disease. The most common clinical symptoms including fever, cough, chill, myalgia and gastrointestinal symptoms. In evaluating the laboratory findings, a significant number of patients showed leukocytosis and thrombocytopenia and increased transaminases.

\section{ACKNOWLEDGEMENTS}

The authors acknowledge the cooperation of Mrs. Zahra Graily (expert in statistics) and the staffs of Ayatollah Rouhani and Shahid Yahyanejad Hospitals, Babol University of Medical Sciences.

\section{CONFLICT OF INTEREST}

All of the authors have declared that no competing interests exist. 


\section{REFERENCES}

1. Ginsberg M, Hopkins J, Maroufi A, Dunne G, Sunega DR, Giessick, J, et al. Swine influenza A (H1N1) infection in two children - Southern California, March-April 2009. Morbidity and Mortality Weekly Report. 2009;58(15):400-402.

2. Clark AM, Nogales A, Martinez-Sobrido L, Topham DJ, DeDiego ML. Functional evolution of influenza virus NS1 protein in currently circulating human 2009 pandemic H1N1 viruses. J Virol. 2017;91:e00721.

3. Veguilla V, López-Gatell H, López-Martínez I, Aparicio-Antonio R, Barrera-Badillo G, Rojo-Medina J, et al. A large proportion of the Mexican population remained susceptible to A (H1N1) pdm09 infection one year after the emergence of 2009 influenza pandemic. PloS One. 2016;11(3):e0150428.

4. Echevarría-Zuno S, Mejía-Aranguré JM, Mar-Obeso AJ, GrajalesMuñiz C, Robles-Pérez E, González-León M, et al. Infection and death from influenza A H1N1 virus in Mexico: a retrospective analysis. Lancet. 2010;374:2072-79.

5. Lee CW, Seo JB, Song JW, Lee HJ, Lee JS, Kim MY, et al. Pulmonary complication of novel influenza A (H1N1) infection: imaging features in two patients. Korean J Radiol. 2009;10:531-4.

6. Salmon DA, Proschan M, Forshee R, Gargiullo P, Bleser W, Burwen $\mathrm{DR}$, et al. Association between Guillain-Barré syndrome and influenza A (H1N1) 2009 monovalent inactivated vaccines in the USA: a meta-analysis. Lancet. 2013;381:1461-8.

7. Launay E, Ovetchkine P, Saint-Jean M, Coïc L, Ducruet T, Charest $\mathrm{H}$, et al. Novel influenza A (H1N1): clinical features of pediatric hospitalizations in two successive waves. Int J Infect Dis. 2011;15: e122.

8. Lapinsky SE. H1N1 novel influenza A in pregnant and immunocompromised patients. Crit Care Med. 2010;38:e52.

9. Baz M, Abed Y, Simon P, Hamelin MÈ, Boivin G. Effect of the neuraminidase mutation $\mathrm{H} 274 \mathrm{Y}$ conferring resistance to oseltamivir on the replicative capacity and virulence of old and recent human influenza A (H1N1) viruses. J Infect Dis. 2010;201:740-5.

10. Du QS, Huang RB, Wang SQ, Chou KC. Designing inhibitors of $\mathrm{M} 2$ proton channel against $\mathrm{H} 1 \mathrm{~N} 1$ swine influenza virus. PloS One.2010;5:e9388.

11. Bautista E, Chotpitayasunondh T, Gao Z, Harper SA, Shaw M, Uyeki TM, et al. Clinical aspects of pandemic 2009 influenza A (H1N1) virus infection. New Engl J Med. 2010:362(18):1708-19.
12. Gouya MM, Nabavi M, Soroush M, Haghdoust AA, Ghalehee S, Hemmati P, et al. Mortality from pandemic influenza A (H1N1) in Iran. Iran Red Crescent Med J. 2011;13:698.

13. Khodadad N, Moattari A, Abadi MSS, Kadivar MR, Sarvari J, Tavakoli F, et al. Prevalence of influenza A(H1N1)pdm09 virus resistant to oseltamivir in Shiraz, Iran, during 2012-2013. Jundishapur J Microbiol. 2015;8:e23690.

14. Creanga AA, Johnson TF, Graitcer SB, Hartman LK, Al-Samarrai T, Schwarz AG, et al. Severity of 2009 pandemic influenza A (H1N1) virus infection in pregnant women. Obstet Gynecol. 2010;115:717-26.

15. Carlson A, Thung SF, Norwitz ER. H1N1 influenza in pregnancy: what all obstetric care providers ought to know. Rev Obstet Gynecol. 2009;2:139.

16. Siston AM, Rasmussen SA, Honein MA, Fry AM, Seib K, Callaghan WM, et al. Pandemic 2009 influenza A (H1N1) virus illness among pregnant women in the United States. JAMA. 2010;303:1517-25.

17. Quispe-Laime AM, Bracco JD, Barberio PA, Campagne CG, Rolfo VE, Umberger R, Meduri GU. H1N1 influenza A virusassociated acute lung injury: response to combination oseltamivir and prolonged corticosteroid treatment. Intensive Care Medicine. 2010;36:33-41.

18. Amorim VB, Rodrigues RS, Barreto MM, Zanetti G, Hochhegger $\mathrm{B}$, Marchiori E. Influenza A (H1N1) pneumonia: HRCT findings. J Bras Pneumol. 2013;39:323-9.

19. Minodier L, Charrel RN, Ceccaldi PE, van der Werf S, Blanchon T, Hanslik T, Falchi A. Prevalence of gastrointestinal symptoms in patients with influenza, clinical significance, and pathophysiology of human influenza viruses in faecal samples: what do we know? Virol J. 2015;12:215.

20. Choi WJ, Kim WY, Kim SH, Oh BJ, Kim W, Lim KS, et al. Clinical characteristics of pneumonia in hospitalized patients with novel influenza A (H1N1) in Korea. Scand J Infect Dis. 2010;42:311-4.

21. Louriz M, Mahraoui C, Azzouzi A, El Fassy Fihri MT, Zeggwagh AA, et al. Clinical features of the initial cases of 2009 pandemic influenza A (H1N1) virus infection in an university hospital of Morocco. Int Arch Med. 2010;3:26.

22. Song JY, Cheong HJ, Heo JY, Noh JY, Yong HS, Kim YK, et al. Clinical, laboratory and radiologic characteristics of 2009 pandemic influenza A/H1N1 pneumonia: primary influenza pneumonia versus concomitant/secondary bacterial pneumonia. Influenza Other Respir Viruses. 2011;5:e535-43. 